\title{
In the VEST trial: are we missed to address the pathology incurred by the external stent?
}

\author{
Vijayanand Palanisamy* ${ }^{*}$, Valikapthalil Mathew Kurian and Rajan sethuratnam
}

\begin{abstract}
In the VEST IV trial, the author concluded that external stenting of saphenous vein graft mitigates its remodeling and also significantly reduces the diffuse intimal hyperplasia and development of lumen irregularities at 4.5 years after coronary artery bypass grafting surgery. We also have valuable a suggestion in addition to external stenting that might nullify the pathology caused by the stent and might enhances graft patency.
\end{abstract}

Keywords: Vest trial, Saphenous vein, Coronary artery bypass grafting

\section{To the Editor,}

We have read the VEST IV trial [1] by David P Taggart and the team, with great expectation. We would like to appreciate the author for their effort to strengthen the weak link in coronary artery bypass grafting (CABG). In their study, the author had shown that the external stenting had aided in maintaining great saphenous vein (SVG) lumen uniformity and hindered the intimal hyperplasia at 4.5 years after CABG.

We would like to bring a major pathology incurred by stent for the author's notice. In VEST IV trial, they have shown that early graft failures in both groups $(30 \%$ stented versus $23 \%$ nonstented SVG, $p=0.42$ ) were comparable. Restrictive annuloplasty for mitral regurgitation would result in functional mitral stenosis/ patient-prosthesis mismatch [2, 3]. Likewise, the valve leaflet coaptation height and the trans-valvular gradient might have increased by deploying the external stent. This might have been led to the accelerated early graft failure in the stented group.

We recommend few modifications in the VEST trial, which will help them, achieve better venous graft patency.

*Correspondence: vetri86@gmail.com

Institute of Cardiovascular Diseases, The Madras Medical Mission, 4A

Mogappair, Chennai, Tamilnadu 600037, India
The arterial system is closed, pressured, and with a potentially bidirectional flow. The presence of a valve in the arterialized venous conduit may hinder this functionality. Whitney et al. did a detailed study using time-lapse angiography throughout 11-year and demonstrated that venous valves cause turbulence and dilatation of the vein segment nearer to the valve [4].

With a flow rate of $10-30 \mathrm{ml} / \mathrm{min}$, valves begin to close and the vein valve's closure creates a pressure trap in the segment distal to the valve. Segmental hypertension results in an accelerated atherosclerotic process in vein grafts [5]. Mills [6] found that venous valves are the potential site for thrombosis with embolization leading to the critical graft disease and named them as "the bad boys".

A simple valvulotomy may be used to split these valves allowing a more even flow and avoiding the air trapping and thrombus formation in the valve recesses. A potential cause for perioperative infarction or early graft failure may be avoided. The potential risk factor for valvulotomy was intimal injury and residual valve inside the vein segment. Using modern valvotomes, studies show that the intimal injury was only minimal and the remnant valves also get resolved during the due course [7].

A study by Monsefi et al. revealed that patients with valvulotomized SVG (v-SVG) had good clinical outcomes with a patency rate of all v-SVG was 97.1 versus $95.8 \%$ of arterial grafts at $18 \pm 6$ months postoperative period [8]. original author(s) and the source, provide a link to the Creative Commons licence, and indicate if changes were made. The images or other third party material in this article are included in the article's Creative Commons licence, unless indicated otherwise in a credit line to the material. If material is not included in the article's Creative Commons licence and your intended use is not permitted by statutory regulation or exceeds the permitted use, you will need to obtain permission directly from the copyright holder. To view a copy of this licence, visit http://creativecommons.org/licenses/by/4.0/. The Creative Commons Public Domain Dedication waiver (http://creativeco mmons.org/publicdomain/zero/1.0/) applies to the data made available in this article, unless otherwise stated in a credit line to the data. 
Intraoperative flow measurements showed a significant increase $(20.2 \mathrm{~mL} / \mathrm{min} ; \mathrm{p}<0.01)$ of flow in the venous bypass grafts after valvulotomy [8].

In 2018, Anli et al. revealed that the mid-term patency of $\mathrm{v}$-SVG was $96.1 \%$ in comparison with $96.7 \%$ for the arterial grafts at $3.1 \pm 2$ years [9].

Lajos et al. [10] found that the patency of sequential, valveless veins was $88.6 \%$ versus $72 \%$ for reversed valvular segments $(\mathrm{p}<0.01)$ when analyzed 436 patients during the follow-up for 8-12 years. They named these valveless veins "good veins". They also added that if good veins were combined with internal mammary arterial graft, the survival of the patient was improved $(\mathrm{p}<0.0057)$.

SVG on average will have 10-12 valves with more valves located in a below-knee position [11]. While performing CABG, a valveless segment of the vein should be preferred. Secondly, if the valve is present then valvulotomy should be done.

It's evident from the VEST IV trial that intimal hyperplasia was hindered by applying external stents thereby delayed graft failure. By deploying external stents over the vein in addition to valveless vein/v-SVG, we can avoid the potential risk factors for both early and late venous graft failure.

\section{Abbreviations}

CABG: Coronary artery bypass grafting; SVG: Great saphenous vein; v-SVG: Valvulotomized great saphenous vein.

\section{Acknowledgements}

Nil.

\section{Authors' contributions}

VP: Associate consultant (Concept/Drafting article), VMK; Senior Consultant (Concept), RS: Senior consultant (Drafting). All authors read and approved the final manuscript.

\section{Funding}

Nil.

\section{Availability of data and materials}

Nil.

\section{Declarations}

Ethics approval and consent to participate

N/A.

\section{Consent for publication}

N/A.

\section{Competing interests}

The authors declare that they have no competing interests.

Received: 21 June 2021 Accepted: 29 August 2021

Published online: 08 September 2021

\section{References}

1. Taggart DP, Webb CM, Desouza A, Yadav R, Channon KM, De Robertis F, Di Mario C. Long-term performance of an external stent for saphenous vein grafts: the VEST IV trial. J Cardiothorac Surg. 2018;13(1):117. https://doi. org/10.1186/s13019-018-0803-9

2. Ma W, Shi W, Wu W, Ma X, Kong Y, Zhu D, Zhang W. Patient-prosthesis mismatch in mitral annuloplasty for degenerative mitral regurgitation: an ignored issue. Eur J Cardiothorac Surg. 2019;56(5):976-82. https://doi.org/ 10.1093/ejcts/ezz086.

3. Kubota K, Otsuji Y, Ueno T, Koriyama C, Levine RA, Sakata R, Tei C. Functional mitral stenosis after surgical annuloplasty for ischemic mitral regurgitation: importance of subvalvular tethering in the mechanism and dynamic deterioration during exertion. J Thorac Cardiovasc Surg. 2010;140(3):617-23. https://doi.org/10.1016/j.jtcvs.2009.11.003.

4. Whitney DG, Kahn EM, Estes JW. Valvular occlusion of the arterialized saphenous vein. Am Surg. 1976;42(12):879-87.

5. Thubrikar MJ, Robicsek F, Fowler BL. Pressure trap created by vein valve closure and its role in graft stenosis. J Thorac Cardiovasc Surg. 1994;107(3):707-16.

6. Mills NL. Saphenous vein graft valves: "the bad guys." Ann Thorac Surg. 1989;48(5):613-4. https://doi.org/10.1016/0003-4975(89)90772-8.

7. Donovan TJ, Lowe R. Biologic fate of valves in reversed and nonreversed arterial vein grafts. Am J Surg. 1985;149(4):435-40. https://doi.org/10. 1016/s0002-9610(85)80035-0

8. Monsefi N, Zierer A, Honarpisheh G, Bauer R, Kerl M, Beiras-Fernandez A, Moritz A. One-year patency of valvulotomized vein grafts is similar to that of arterial grafts. Thorac Cardiovasc Surg. 2016;64(3):204-10. https://doi, org/10.1055/s-0035-1549009.

9. Anli S, Karimian-Tabrizi A, Moritz A, Monsefi N. Mid-term clinical outcome of patients undergoing coronary artery bypass grafting with valvulotomized vein grafts. Heart Surg Forum. 2018;21(4):E269-74. https://doi.org/ 10.1532/hsf.1960

10. Lajos TZ, Robicsek F, Thubrikar M, Urschel H. Improving patency of coronary conduits "valveless" veins and/or arterial grafts. J Card Surg. 2007;22(2):170-7. https://doi.org/10.1111/j.1540-8191.2007.00380.x.

11. Bosher $L P$, Deck JD, Thubrikar M, Nolan SP. Role of the venous valve in late segmental occlusion of vein grafts. J Surg Res. 1979;26(4):437-46. https:// doi.org/10.1016/0022-4804(79)90032-5.

\section{Publisher's Note}

Springer Nature remains neutral with regard to jurisdictional claims in published maps and institutional affiliations. 